\title{
Review of Creative Nature (part 3)
}

\author{
GEOFFREY WOOLLARD \\ Department of Medical Biophysics, \\ University of Toronto, Canada \\ geoff.woollard@mail.utoronto.ca \\ ORCID: 0000-0001-5440-4228
}

\begin{abstract}
The short monograph Creative Nature (Francisco Javier Novo, Rubén Pereda, and Javier Sánchez-Cañizares. 2018. Naturaleza Creativa. Madrid: Rialp. ISBN: 978-84321-4916-0. 196 pp. Paperback, €14.25) is a welcome contribution to the philosophy of nature that arose from interdisciplinary conversations between authors who are both up-to-date in the scientific literature and deeply grounded in the Western intellectual tradition. In this third and final part of the review essay, I take Creative Nature as a point of departure and develop a theological synthesis of our relationship with the natural world. My approach to making sense of natural evil draws on the Aristotelian-Thomistic metaphysical tradition. I emphasize the wisdom of viewing nature as a whole and avoiding anthropomorphisms, in order to both come to peace with our common home and feel like we belong in a welcoming world. I draw from St. Paul's teaching on cosmic redemption in his letters to the Colossians and Ephesians to shine the light of supernatural faith on our relationship with the natural world. This approach illustrates how a sound philosophy of nature and biblical interpretation are pivotal for faith-science dialogue.
\end{abstract}

Keywords: relationship to nature; anthropomorphism; natural evil; diversity of life; cosmic redemption. 


\section{Acknowledgements}

The author would like to thank Dr. John G. Brungardt for many fruitful discussions and editorial contributions. While we co-authored the first two parts of this review essay, at his request, and out of fairness to us both, I take sole responsibility for any inadequacies in this third part.

\section{Introduction: our relationship with the natural world}

"Everything is connected" (Francis 2015, 91, 117). Living systems are in constant communication in a "web of relationships" (Francis 2015, 240). From the time of early naturalists to contemporary scientists, empirical studies allow us to understand the grammar of structure and function at various scales, from atoms to ecosystems (Woollard and Brungardt 2020, 246-254). Our physical solidarity ${ }^{1}$ with our fellow creatures naturally gives rise to a caring attitude: we want to protect our common home, because we see ourselves as part of nature and vitally interwoven with everything in the past, present, and future. While death and decay seem inherent in evolutionary change, this is not incompatible with a welcoming planet where we belong. However, to have a healthy relationship with the natural world requires scientific results to be taken up into a sound philosophy of nature and synergized with the light of faith. Here I propose such a synthesis by synergizing recent advances in philosophy of nature-proposed by Novo, Pereda and Sánchez-Cañizares (Novo et al. 2018)-and Pope Francis's encyclical letter Laudato Si' (Francis 2015).

Creative Nature emphasizes an open future, filled with hope, where "we can hold onto the hope that our covenant with Nature will one day be healed" (Novo et al. 2018, 14; Woollard and Brungardt 2019, 265). What happens when the sun does not seem to shine in the garden; when the storms come, or death and decay work in the shadows? The theologian Denis Edwards takes Laudato Si'-which Francis reminds us “is now added to the body of the Church's social teaching” (Francis 2015, 15) - as a point of

1 See “solidarity” in Francis 2015, 14, 58, 142, 148, 158, 159, 162, 172, 210, 227, 232, 240 
departure, and addresses this challenging theme by drawing on the theology of the cross-theologia crucis. The randomness of genetic mutations and the contingency of meteorites hitting Earth shape the path of evolution. Beyond this, Edwards is engaging

the costs of evolution, costs built into the process: the loss, the pain, the predation, the deaths, the extinctions of most species that ever lived over the 3.8 billion year history of life [...]. In my view, a theology of the cross, a theology of God with suffering creation, is needed to speak in some way to this violence. (Edwards 2016, 379-380)

Life is not all "Sunshine, Lollipops And Rainbows" as the 1960s hit song goes. Edwards proposes sublime communion ${ }^{2}$ as a way to make sense of the storm clouds, thunder, and shadows that are also a part of strolling through the park (Novo et al. 2018, 15-22; Woollard and Brungardt 2019, 251). He contrasts beauty/fittingness/reasonability with

the sublime when it throws our notions of reason, order, and proportion into utter confusion, when it points to what is totally beyond us, to the incomprehensible. [...]

This line of thought suggests that "sublime communion" could be developed to embrace what is not taken up in Laudato Si', the pain, the deaths, the chaos, the randomness, the ugliness of so much of the natural world. [...] And it could embrace the costs of evolution as well as the beauty and rich diversity of life around us. (Edwards 2016, 390)

Philosophy is a mediator of dialogue between science and religion (Woollard and Brungardt 2020, 254-257). Philosophy of nature mediates between empirical studies and metaphysics (Woollard and Brungardt 2019, 248-249, 265-266), In this third and final part of the review essay we will draw on insights from the Aristotelian-Thomistic metaphysical tradition and engage with St. Paul's teaching on cosmic redemption. Philosophy of nature can

2 The phrases "sublime communion" (Francis 2015, 89) and "sublime fraternity" (Francis 2015, 221) are used in Laudato Si' to express the familial belonging and solidarity we have with our fellow creatures. 
help a theology of the natural world in three ways: through (1) not overly anthropomorphizing, (2) helping us understand God's providence in the natural evils of death and decay, and (3) showing how diversity in creation manifests the glory of our loving Creator.

\section{Anthropomorphic blind spots}

A preliminary step to Edward's proposal is to ensure that we are not perceiving a cross where none objectively exists. Certainly, our alienation and disharmony from the natural world is apparent through humanity's meaningless cruelty, the destruction of natural habitats, loss of biodiversity, and addictive consumerism. The theme of a right relationship between the human person and the natural world has been prominent in cinema and literature as an ecological reaction to the dominance of technology in the twentieth century (Bouyer 1988). The destructive possibilities of technology that work against our integral development are highlighted in such films as Nausicaä of the Valley of the Wind (1984), Princess Mononoke (1997) (both from Hayao Miyazaki/Studio Ghibli), and the award winning short film The Man Who Planted Trees (1987), just to mention a few that are my special favourites.

The intrinsic value of individual organisms certainly deserves emphasis to correct an overly-utilitarian stance. To this end Laudato Si' criticizes modern anthropocentrism, in continuity with Romano Guardini's critique of modernity's technocratic paradigm. ${ }^{3}$ And so we will examine natural harmony and shift our focus more towards the "harmonious ensemble of organisms existing in a defined space and functioning as a system" (Francis $2015,140)$. Rather than despotic dominion, or self-destructive withdrawal, we could have a mature, scientific, and friendly relationship with our fellow creatures, "where humans receive from other creatures what they need for their sustenance, and humans in turn protect and care for their

3 See Guardini (1998), originally published in 1950 in German as Das Ende der Neuzeit and cited eight times in five paragraph points of Laudato Si' (Francis 2015, 105, 108, 115, 203, 219). 
fellow creatures" (Edwards 2016, 381). When discussing the perfection of the universe St. Thomas states that "the good of the species is greater than the good of the individual, just as the formal exceeds that which is material. Hence, a multiplicity of species adds more to the goodness of the universe than a multiplicity of individuals in one species" (Aquinas 1918, $S c G$ II.45). ${ }^{4}$ If we can draw on philosophy of nature when we frame the question of natural evils, we can take into account their full identity, and avoid abstracting them away from objectivity and anthropomorphizing them into something they are not.

From a young age we learn that the circle of life involves animals feeding on plants and other organisms. This circle spirals into the microscopic world of metabolic pathways that underlie the bioenergetics of life as we know it: autotrophs harness solar energy through photosynthesis and build up complex organic molecules (lipids, carbohydrates, amino acids) while heterotrophs release energy through breaking down these complex molecules through oxidative phosphorylation and glycolysis. Cycles of various elements (nitrogen, carbon, phosphorus, etc) in the air, water and soil are in a fragile balance. Being a part of nature, we humans have a material solidarity with all of our non-human neighbours.

Without the flow of time and change, without death and decay, how can a harmonious ensemble exist? A mature philosophy of nature educates our emotions and helps overcome a jejune vision of the non-human world that is perhaps reinforced at an early age through entertainment. Consider just a snapshot of films from my experience: cf. Bambi (1942), The Jungle Book (1967), The Many Adventures of Winnie the Pooh (1977), and other Disney films; Rock-a-Doodle (1991), FernGully: The Last Rainforest (1993), Finding Nemo (2003) and other Pixar films, March of the Penguins (2005) and other nature documentaries. Although not all of these films are intended solely for young children, they anthropomorphize animals in a way that is central to the story. In Disney's Robin Hood (1973), Robin is a clever fox, Prince John's sneaky servant Sir Hiss is a snake, and the folk-singer-narrator is

4 James F. Anderson translation (Aquinas 2018a). 
a wise ol' country Rooster. In fact, it is hard to think of literature involving animals that does not do so, not just kids' films and nature documentaries. Perhaps this is because we have a hard time bonding affectively with beings that are not in our image and likeness, that are not personal.

\section{The mystery of natural evil}

Does the perfection of the universe somehow need death and decay? Is a universe without natural evil possible? Or perhaps we read suffering and pain into the natural world, when nothing like human pain and suffering objectively exists. Does nature share in the fall, narrated by Genesis and other religious texts? In this section we bracket out moral evil from the discussion at hand. I am taking "natural evil" 5 to mean some privation of a being's good. This natural evil underlies all sorts of change that science examines: a tree burning in a forest fire, a spider catching an insect in its web and consuming it. In nature there are many things and they are different. What is good for one can be bad for another. A forest needs the intense heat of a forest fire to breathe new life into it.

C. S. Lewis reflected deeply on these questions in The Problem of Pain (Lewis 2016). Lewis cautions against overspeculation, "God has given us data which enable us, in some degree, to understand our own suffering: He has given us no such data about beasts. We know neither why they were made nor what they are, and everything we say about them is speculative" (Lewis 2016, 83). The philosopher Thomas Nagel shines some light on our anthropomorphic blind spot. He distinguishes between imagining what it is like to be an animal, and what it is like for me to be an animal. ${ }^{6}$ If we

\footnotetext{
Some authors use the term "physical evil."

6 "It will not help to try to imagine that one has webbing on one's arms, which enables one to fly around at dusk and dawn catching insects in one's mouth; that one has very poor vision, and perceives the surrounding world by a system of reflected high-frequency sound signals; and that one spends the day hanging upside down by one's feet in an attic. In so far as I can imagine this (which is not very far), it tells me only what it would be like for me to behave as a bat behaves. But that is not the question. I want to know what it is like for a bat to be a bat." (Nagel 1974, 438)
} 
acknowledge Nagel's distinction as insightful, we can still look to Lewis for answers to three questions: (1) the fact of animal suffering, (2) its origin, and (3) its fairness. Lewis answers the second question, "How did disease and pain enter the animal world?" (Lewis 2016, 84), not so much by man's fall, since "carnivorousness, with all that it entails, is older than humanity" (Lewis 2016, 86). Instead, Lewis points his finger at another free being, the Evil One. "If there is such a power, as I myself believe, it may well have corrupted the animal creation before man appeared. The intrinsic evil of the animal world lies in the fact that animals, or some animals, live by destroying each other" (Lewis 2016, 87).

St. Thomas ${ }^{7}$ also reflected deeply on these questions, and confidently concludes where Lewis tentatively speculates. He writes about other living beings through the lens of the relationship of the human person with nature, and how our oversight and responsibility for living beings changes with ignorance, ill will, weakness, and unbalanced desires (Aquinas 1889; ST I, q. 96, I-II, q 85, a. 3). Aquinas' anthropology is rooted in the unique metaphysical relationship of our actualizing principle (our form, an incorruptible soul) to our potential principle (our matter, a body). These distinctions, plus his faith-filled answer to the loss of original justice by our first parents (Aquinas 1889; ST I, q. 97, a. 1), are at the basis of his answers to questions regarding whether death and other bodily defects are effects of sins (Aquinas 1892; ST I-II, q. 85, a. 5) or are natural to us (ibid., a. 6). This stance is not unanimous in the Christian tradition, as Fr. Thomas Davenport, O.P., explains in a recent collection of essays about Thomistic thought and evolution.

[We] might wonder if the physical evil of animal violence is really just a manifestation of sin, something that was foreign to God's original plan but that $\mathrm{He}$ allows for a time in order to redeem it in the future. In fact, some Fathers of the Church thought exactly this, seeing the bloodiness of nature as a defect resulting from the fall of Adam and claiming that all creatures are plants in Paradise.

See St. Thomas, $Q D d P$, q. 5, a. 9, c., In I Sent., d. 44, q. 1, a. 2, and commentary in Brungardt 2018. 
[... I]t is interesting to see that St. Thomas rejects this view, arguing that moral evil has many negative effects, including corrupting human nature, but it does not destroy our nature or the nature of other things. Sin is not powerful enough to change what an animal eats. (Davenport $(2016,106)$ citing Aquinas (1889; $S T$ I, q. 96, a. 1, ad 1; ST I-II, a. 85))

The answers to these mysterious questions weave our relationship with nature. Answers hinge on what we consider evil, which hinges on our philosophy of nature and metaphysics. Scholastic thought proceeded logically and arrived at unexpected results such as "while it is absolutely possible for God to have made a universe without evil in it, such a universe would not be better than this universe!” (Brungardt 2018). Brungardt explains the underlying metaphysics.

[F]irst, in any change, something is first in a state contrary to what it will be in at the end of the change (first it is here, then there, an object is first hot then cold, etc.). This means that any change where one object suffers a change to a worse state (and this is especially evident in living things) implicates the principle of contrariety. Second, apart from contrariety in changes, there is also contrariety in the agent causes bringing about change. An agent must act on a patient, and this is not always a good thing for the patient. Again, this is especially clear in the biosphere-food is only a fruit of death. [...]

Thus, the root reason for the apparent logical impossibility of God to make a material universe free of natural evils lies, radically, in the nature of matter. This is not because matter itself is evil, but rather because matter is the potentiality for a range of goods, some of which are contrary to each other and in various respects incompatible. In other words, the essence of the physical cosmos consists in an order of substances that are intrinsically composed of parts that of their nature permit contrariety and defect. A physical universe without these principles would really just be a universe full of angels by a different name. (Brungardt 2018)

Thus universal sameness is no solution for our changing and dynamic universe. God's goodness is so rich that a diversity of beings better expresses his goodness. Aquinas explains why it makes sense that God's providence permits natural evil. 
And so, if complete equality were present in things, there would be but one created good, which clearly disparages the perfection of the creature. [...] It would be contrary to the rational character of the divine regime to refuse permission for created things to act according to the mode of their nature. Now, as a result of this fact, that creatures do act in this way, corruption and evil result in things, because, due to the contrariety and incompatibility present in things, one may be a source of corruption for another. Therefore, it does not pertain to divine providence to exclude evil entirely from the things that are governed. (Aquinas 2018b, ScG III.71) ${ }^{8}$

Animals live and die; chemical reactions start and stop. Anthropomorphising a chemical bond breaking, a protein misfolding, or a bacteria cell lysing, as if it were a human breaking an arm is a lack of imagination to say the least. We are on the wrong track if we anthropomorphize a big fish eating a little fish as if we were the fish and we were being eaten. With this perspective, we can hopefully notice how each creature manifests the glory of our Creator.

\section{The diversity of us creatures manifests the glory of our Creator}

As open systems, living beings require energy and resources for their growth and development. Historically, common parlance has distinguished plants and animals but empirical studies allow us to refine these categories and account for photosynthetic protists and carnivorous plants, one of which is large enough to digest a mouse (McPherson 2009), a topic discussed academically as early as Darwin's book on carnivorous plants (Darwin 1875). Recent genome sequencing studies support convergent evolution of carnivory at a molecular level (Callaway 2017), including plant carnivory nine times. ${ }^{9}$ Various evolutionary lineages have evolved carnivorous digestive enzymes that capture phosphorus and nitrogen from prey. These plants have their own creative ways of fitting in the ecosystem, including a humble mutualism

8 Vernon J. Bourke translation.

$9 \quad$ See Givnish (2015) and other citations in Pavlovič and Saganová (2015).

ScientiaetFides $8(2) / 2020$ 
with the mountain shrew that offers a nitrogen source in its droppings in exchange for feeding on small outgrowths of the plant's circulatory system (Clarke et al. 2009). Carnivorous plants also offer a gift for humans, in the form of medicinal compounds that can heal us from pathogenic fungal infections (Eilenberg et al. 2010). Delving into the details of empirical studies can help us contemplate carnivorous plants and listen to their message. Yes, even theirs. In our stroll through the park we no longer see carnivorous plants as theatrically depicted in Little Shop of Horrors (1960; 1986). Instead we have a more mature vision of how nature works and our place in its sublime communion.

Let us return to the crossroads at which Edwards stands, but without anthropomorphic blindspots and more aware of the mystery of natural evil. I sympathize that the astute reader may be able to provide confounding examples to challenge the perspective that "Nature as a whole not only manifests God but is also a locus of his presence," and that "the Spirit of life dwells in every living creature and calls us to enter into relationship with him." ${ }^{10}$ Edwards proposes that contributions from theology can shed light into this deep mystery.

A theology of the natural world as sublime communion could recognize [...] that without faith the world might seem highly ambiguous to us, as both beautiful and violent. A theology of the sublime communion of creation would be based not simply on observation of the natural world, but on the revelation given in Christ that, in spite of appearances, in spite of what can seem like the violent and dark side of nature, the emergent and evolving creation is the work of unthinkable and incomprehensible love. [... A]long with proclaiming the incarnation and the cross as God's identification with suffering creation, it would proclaim the resurrection of the crucified Jesus as the unbreakable promise of God to the whole creation. (Edwards 2016, 390-391)

Perhaps some theological presuppositions are nesting in this quotation. I suggest we keep in mind the finer points of Christology, with its hard-won historical precision and distinctions. While Edwards does not assert it,

10 Francis 2015, 88, citing National Conference of the Bishops of Brazil (1992). 
there may be in the background deeper theological issues with kenoticism and divine impassibility. We must be clear about how Christ suffered and "empties himself" (Phil 2:7) and the nature of his redemptive act in relation to his humanity and his divinity. ${ }^{11}$ Theological discourse of the being of God and its "identity" with suffering calls for further precision. Talk of "identity" can also run a bit loose when it comes to the mode of being of the Incarnation. Thus, it is important to collaborate closely with theological experts in Christology when pondering these mysteries.

We can contrast Edwards' perspective with that of a theologian who has been closely following the scientific literature. After citing St. Thomas' question on God as the source of multiplicity and diversity (Aquinas 1888, $S T$ I, q. 47, a. 1), the priest-scientist Fr. Nicanor Pier Giorgio Austriaco, O.P., reframes the costs of evolution by considering the whole evolutionary timeline.

[In creating via evolution, God] was able to create more species to reflect his glory: Four billion species created over a three billion year period rather than just the eight million extant species today. In fact, it would have been ecologically impossible for all four billion species to co-exist on our planet, because there are only a limited number of ecological niches on the planet at a given moment in time.

[...] If they had been created together, the large carnivorous dinosaur, $T y-$ rannosaurus rex, would have wiped out the Asian elephant, Elephants maximus. However, with evolutionary creation [...] these species were able to exist at separate moments in history to uniquely manifest the glory of their Creator. (Austriaco 2016, 196)

No creature exhausts the limitless uncreated esse of the Creator. We need diversity to grasp aspects of our Creator who is infinitely inexhaustible.

\section{Cosmic redemption}

What exactly is meant by the phrase "God redeemed his creation"? First of all, we must strive to understand such locutions properly and not univocally

11 For a recent treatment of these and related issues, consider White (O.P.) 2015. 
attribute to the whole (all creation) what the locution attributes to only a part (i.e., us) through a figure of speech. St. Paul's letters to the Colossians and Ephesians teaches how the whole cosmos is oriented to Christ. ${ }^{12}$

He is the head of the body, the Church; he is the beginning, the first-born from the dead, that in everything he might be pre-eminent. For in him all the fullness [ $\pi \lambda \eta \dot{\rho} \omega \mu \alpha$, plêroma] of God was pleased to dwell, and through him to reconcile to himself all things, whether on earth or in heaven, making peace by the blood of his cross. (Col 1:18-20)

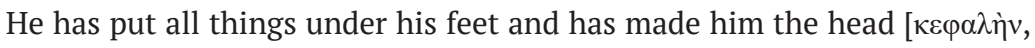
kephalēn] over all things for the Church, which is his body, the fullness of him who fills all in all. (Eph 1:22-23)

Everything is created by Him, in Him and through Him (Col 1:16). He contains

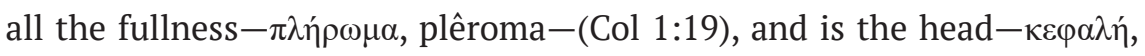
kephalē-(Eph 1:22). This orientation does not only reside on a distant astronomical level, but also in the smallest, humblest and most microscopic aspects of creation. Biblical scholars point out that St. Paul's motivation in writing these letters is to address certain Jewish-Gnostic trends in the respective communities, and to put Christ in the centre of everything as its head. In his study of the New Testament, the German theologian Joachim Gnilka gives the cultural and linguistic backdrop of the Christological hymn in Colossians.

They refer to the subterranean, cosmic, angelic powers or forces of destiny. In Judaism the angels were venerated. In Hellenism the forces of destiny were feared, it was thought that men were controlled by them and there was talk of Ananké and Heimarmené. This fear of destiny could be related to the stars; the destiny of man, to the course of the stars. Christ is above all of these powers, abilities and forces of destiny. He is the head.

Here the image of the body is illustrated. The widespread vision of the world in antiquity was as a man of great dimensions, a macroanthropos, body

12 The following section is best read with Col 1:15-20 and Eph 1:16-23 on hand for a fuller context. 
and organism. As head, Christ-Logos rules over that body, maintaining its order and consistency. (Gnilka 1998, 346-347) ${ }^{13}$

When St. Paul addresses the primacy of Christ for all of creation he certainly does not bracket off humanity and only consider the natural world. Through the cosmic texts of St. Paul, Gnilka explains how "everything has reached the goal of salvation.”

For to the extent that the fullness of being dwelt in him, to the extent that he embraced everything in his resurrection, he has reconciled and pacified everything. This not only affirms the reconciliation of man, but also the pacification of disparate and dispersed forces of nature. (Gnilka 1998, 347)

Furthermore, when St. Paul brings up humanity, he tends to also bring up the Church. What is being redeemed here seems to be our relationship with the natural world; if not more. Christ is a reference point for making sense of how we are to relate to the world, and where things are headed. Exactly what $\pi \lambda \eta \dot{\eta} \rho \omega \mu \alpha$ and $\kappa \varepsilon \varphi \alpha \lambda \eta ́$ refer to here is an ongoing scholarly discussion and should be read in the context of the whole corpus paulinum.

[I]t is likely that St. Paul used some of the ideas and aspirations of Gnostics to speak to the Christians of Asia Minor with a religious language that was habitual for them. We could explain things as follows: when the captivity letters insist on the concept of pleroma or perfect totality, and refer to Christ as the «head» of the cosmos, they are discussing the Redemption not in individual terms, but universal terms. The Incarnation produces a «marriage» of God with humanity. (Basevi 2013, 173) ${ }^{14}$

The new testament scholar Alessandro Sacchi, after explaining the backdrop of the "dangerous gnostic heresy," summarizes the main message of Colossians: "unity of the Church in Christ."

My translation. Also see numerous references therein.

14 My translation. 
In the Christological hymn (1:15-20) he is presented as the mediator of creation (1:15) [...] By the work of Christ, believers were freed from the power of darkness and became part of the kingdom of the beloved Son, thus receiving redemption and the forgiveness of sins (1:13-14); in this way they were reconciled not only with God, but also with the universe (1:20).

[...] The Church therefore defines itself starting from the unity of all its members, in which the final reconciliation of all things is prefigured. While continuing to be a local reality (4:15), it assumes a universal dimension, since in it and through it Christ already realizes his cosmic lordship. (Sacchi 2006, 202-203) ${ }^{15}$

Thus, it seems natural to consider redemption by addressing us as sinners first and then, from that as a principle, addressing issues of our relationship with the natural world, healed by a life in Christ. These relationships have a place in the social doctrine of the Catholic Church which challenges the human community to be energetically engaged in roles of governing and oversight, and not to be passively resigned to a cynical withdrawal in the sight of pathological visions of economic growth (Francis 2015, 163-201). We not only belong in nature, but are responsible for maintaining the fragile balance of things, and re-establishing relationships and natural cycles of growth and healing, which at times means maintaining prudent restraint.

For Paul, the world was not derived from the devil, nor did it belong to the devil. We may not sacrifice the world and give it up to its fate, in spite of its sad history, its misery, and its burden of sin, for the world needs salvation and it is susceptible to salvation. We cannot refrain from all action and activity and leave the world to its own designs. (Holzner 2002, 493)

The roots of the idea of creation as a song the Creator sings-Carmen Dei-run deep: they extend to St. Bonaventure, St. Augustine, St. Paul $\left(\right.$ Casarella 2006, 494) ${ }^{16}$ and surely others. Creative Nature illustrates how nature is a system (Novo et al. 2018, 22-30; Woollard and Brungardt 2019, 251-253), with harmonious notes making a symphony of relationality. We can not only listen to this system, but also discover its grammar and sing

15 My translation. Also see numerous references therein.

16 See Pauline themes in the writing of John Polkinghorne, discussed by Casarella (2006). 
along in accompaniment (Salt and Light Catholic Media Foundation 2015). Thus, when we consider natural evil should we not use this perspective of the whole? For Edwards and ourselves, an implicit conception of natural evil underlies and shapes our relationship to the natural world, and intermingles with our awareness of God as a loving Father. Different starting points will surely lead down different roads. The first sentence of Aquinas' prologue to On Being and Essence quotes from Aristotle's De Caelo, "A small error at the outset can lead to great errors in the final conclusions" (Aquinas 1997).

The poet Wendell Berry expresses a vision of humanity in harmony with nature in his Sabbath poems. His poetry reframes how we experience nature and encourages an ecological conversion (Francis 2015, 216-221). Berry has been publishing poems in this style at least since the late 1970s-around ten per year (Berry 2013). In a Sabbath poem from 2011 he reacts against urban sprawl and overly destructive practices of farming and resource extraction. ${ }^{17}$

New come, we took fields

from the forest, clearing, breaking

the steep slopes. And this was

a fall from a kind of grace:

from the forest in its long Sabbath,

By leaving it alone, we are

in a manner forgiven.

By keeping intact

its gift of self-renewal, not

as our belonging, but asking how

we might belong to it, what we might use of it

for ourselves, leaving it whole, we may come to live in its time, in which our lives will pass

17 Wendell Berry is based in Kentucky, USA. He is also a farmer, activist, academic, elected member of the Fellowship of Southern Writers, a recipient of The National Humanities Medal, and the Jefferson Lecturer for 2012 (Wikipedia 2019). 
as pass the lives of birds

within the lives of trees. (Berry 2013, 370-371)

The poem ends with a vision of how we can be in better harmony with nature by learning from its feature of self-renewal. Human wisdom is wedded to care ("keeping intact its gift of self-renewal"), patient humility ("leaving it alone”), watchful listening ("leaving it whole”), and accepting our limited place in creation ("asking how we might belong to it"). By listening to the lessons of other creatures, we can learn to self-renew and belong.

Berry has an older Sabbath poem from 1979 about time and death and what he calls the "final Sabbath."

This is the way of death: loss of what might

Have been in what must come to be

One grand motion, implacable, sublime.

The calling of all creatures is design.

We long for what can be fulfilled in time, Though death is in the cost. There is a craving As in delayed completion of a rhyme

The fall returns. Our deeds in days gone by

Take root, bear fruit, and are carried on, in faith

Or faults, through deaths all mortal things must die,

The deaths of time and pain, and death's own death

In full-filled light and song, final Sabbath. (Berry 2013, 21-22)

Christ's redeeming love heals all aspects of our being, and his healing extends beyond us to the cosmos. Life in Christ makes death bear fruit. In his death and resurrection, our death and also the death of our fellow creatures renew the cosmos with life. 


\section{Conclusion}

We see only dimly into the future, and St. Paul was intentionally restrained and silent in his eschatology (1 Cor 13:12). Science shines its own light ahead, through the extrapolation of past patterns into the future. Poets like Berry articulate how we reach out in the dark and make sense of what we are living through in our walk through our common cosmic home. Creative Nature, from the perspective of philosophy of nature, ends with a humble invitation to look towards the future with joy and hope; "[i]n an unfinished universe, each of our actions not only contributes to the present but also becomes available for the future" (Novo et al. 2018, 183). While the authors were aware of the limitations and also strengths of their methodology, I have synergized them with theological perspectives with the intent of going "beyond the attempt to unravel the structures and processes hidden in Nature. [...] Put[ing] into practice our effort, our creativity and our enthusiasm and thus cooperating to nourish the hope that this seemingly broken physical world will one day be healed and make sense" (ibid.). I hope our reflection can inspire a further elaboration of how the light of faith, rooted in a sound biblical theology, shines a light on our relationship with the natural world. Edwards highlights an important aspect in our stroll through our common home: we will not understand the message of everything. Indeed, we will not understand things completely free of anthropomorphisms. We will not possess complete mastery and control over Nature's creativity. Yet we can still be at home.

\section{References}

Aquinas, St. Thomas. 2018a. Summa Contra Gentiles. Translated by James F. Anderson. Accessed 11 February. https://dhspriory.org/thomas/ContraGentiles2.htm Aquinas, St. Thomas. 2018b. Summa Contra Gentiles. Translated by Vernon J. Bourke. Accessed 11 February. https://dhspriory.org/thomas/ContraGentiles3a.htm Aquinas, St. Thomas. 1997. De Ente et Essentia. Translated by Robert T. Miller. https:// sourcebooks.fordham.edu/basis/aquinas-esse.asp 
Aquinas, St. Thomas. 1889. Opera Omnia Iussu Leonis XIII P. M. Edita, t. 5: Pars Prima Summae Theologiae Qq. 50-119. Vol. 5. 50 vols. Romae: Ex Typographia Polyglotta S. C. de Propaganda Fide.

Aquinas, St. Thomas. 1888. Opera Omnia Iussu Leonis XIII P. M. Edita, t. 4: Pars Prima Summae Theologiae Qq. 1-49. Vol. 4. 50 vols. Romae: Ex Typographia Polyglotta S. C. de Propaganda Fide.

Austriaco, Nicanor Pier Giorgio. 2016. “The Fittingness of Evolutionary Creation.” In Thomistic Evolution: A Catholic Approach to Understanding Evolution in the Light of Faith, 187-197. Providence, RI: Cluny Media.

Basevi, Claudio. 2013. "Las Epistolas de la Cautividad (II). Efesios y Colosenses: Los Destinatarios.” In Introducción a los Escritos de San Pablo: Su Vida y su Teología, 155-173. Madrid: Pelicano, Palabra.

Berry, Wendell. 2013. This Day: Sabbath Poems, Collected and New 1979-2013. Berkeley, CA: Counterpoint.

Bouyer, Louis. 1988. “The Ecological Reaction.” In Cosmos: The World and the Glory of God, 159-160. Petersham, MA: St Bede’s Publications.

Brungardt, John G. 2018. “Quaestio Quodlibet Whether God Could Have Made a Better Universe or the Existence of Radical Natural Evil.” Only a Philosopher: The personal website of John G. Brungardt, Ph.D., February 11. https://johngbrungardt. com/2018/02/11/quaestio-quodlibet-whether-god-could-have-made-a-betteruniverse-or-the-existence-of-radical-natural-evil/

Casarella, Peter. J. 2006. “Carmen Dei: Music and Creation in Three Theologians.” Theology Today 62(4): 484-500.

Callaway, Ewen. 2017. “How plants evolved into carnivores.” Nature. Accessed 25 November 2018. http://doi.org/10.1038/nature.2017.21425

Clarke, C. M., Bauer, U., Lee, C. C., Tuen, A. A., Rembold, K., and J. A. Moran. 2009. "Tree shrew lavatories: A novel nitrogen sequestration strategy in a tropical pitcher plant.” Biology Letters 5(5): 632-635.

Darwin, Charles. 1875. Insectivorous plants. London: John Murray. Accessed 21 November 2018. http://darwin-online.org.uk/converted/pdf/1875_Insectivorous_F1217.pdf

Davenport, Thomas. 2016. “Divine Providence and the Mystery of Evil.” In Thomistic Evolution: A Catholic Approach to Understanding Evolution in the Light of Faith, 103-108. Providence, RI: Cluny Media.

Edwards, Denis. 2016. “'Sublime Communion’: The Theology of the Natural World in Laudato Si.” Theological Studies 77(2): 377-391.

Eilenberg, H., Pnini-Cohen, S., Rahamim, Y., Sionov, E., Segal, E., Carmeli, S., and A. Zilberstein. 2010. "Induced production of antifungal naphthoquinones in the 
pitchers of the carnivorous plant Nepenthes khasiana.” Journal of Experimental Botany 61(3): 911-922.

Francis (Pope). 2015. Encyclical Letter Laudato Si' [Praise Be To You] On Care for Our Common Home. Vatican City: Vatican Press.

Gnilka, Joachim. 1998. “Teología Post-paulina. Las Cartas a los Colosenses y a los Efesios.” In Teología del Nuevo Testamento. Biblioteca De Ciencias Bíblicas y Orientales, 344-368. Madrid: Editorial Trotta.

Guardini, Romano. 1998. The End of the Modern World. Wilmington, DE: ISI Books. Holzner, Josef. 2002. “Christ's Work of Reconciliation.” In Paul of Tarsus, 489-495. Hounslow, UK: Scepter.

Lewis, Clive Staples. 2016. “Animal Pain.” In The Problem of Pain. Québec, QC: Samizdat University Press, 83-92.

McPherson, S.R. 2009. “The Discovery of Nepenthes attenboroughii.” In Pitcher Plants of the Old World. Volume 2, 1320-1333. Poole: Redfern Natural History Productions.

Nagel, Thomas. 1974. “What Is It Like to Be a Bat?” The Philosophical Review, 83(4): 435.

National Conference of the Bishops of Brazil. 1992. A Igreja e a questão ecológica: leitura ético-teológica a partir da análise crítica do desenvolvimento, 53-54. São Paulo: Edições Paulinas.

Novo, Francisco J., Pereda, Rubén and Javier Sánchez-Cañizares. 2018. Naturaleza Creativa. Madrid: Railp.

Pavlovič, A., and M. Saganová. 2015. "A novel insight into the cost-benefit model for the evolution of botanical carnivory.” Annals of Botany 115(7): 1075-1092. https://doi.org/10.1093/aob/mcv050

Sacchi, Alessandro. 2006. “La Lettera ai Colossesi.” In Logos - Corso Di Studi Biblici, 6: Lettere Paoline e Altre Lettere, $2^{a}$ ristampa, 156-173. Torino: Libreria Elledici.

Salt and Light Catholic Media Foundation. 2015. Creation: Grammar of Creation, https://saltandlighttv.org/creation/

White, Thomas Joseph. 2015. The Incarnate Lord: A Thomistic Study in Christology. Washington, DC: Catholic University of America Press.

Wikipedia. 2019. “Wendell Berry” Accessed 9 January 2019. https://en.wikipedia. org/wiki/Wendell_Berry

Woollard, Geoffrey and John G. Brungardt. 2019. "Review of Naturaleza creativa." Scientia et Fides 7(1)/2019: 247-267. http://dx.doi.org/10.12775/SetF.2019.012 Woollard, Geoffrey and John G. Brungardt. 2020. "Review of Creative Nature (part 2)." Scientia et Fides 8(1)/2020: 245-266. http://dx.doi.org/10.12775/SetF.2020.011 